\title{
ENZOOTIC BOVINE LEUKOSIS: DEVELOPMENT OF AN INDIRECT ENZYME LINKED IMMUNOSORBENT ASSAY (I-ELISA) IN SEROEPIDEMIOLOGICAL STUDIES
}

\section{Ester Teresa González ${ }^{1 *}$, Estela Beatriz Bonzo ${ }^{2}$, María Gabriela Echeverría ${ }^{1,3}$, María Licursi ${ }^{1}$, María Elisa Etcheverrigaray ${ }^{1}$}

${ }^{1}$ Area of Virology, Faculty of Veterinary Sciences, National University of La Plata, La Plata, Argentina. ${ }^{2}$ Area of Epidemiology, Faculty of Veterinary Sciences, National University of La Plata, La Plata, Argentina. ${ }^{3}$ Researcher of National Research Council (CONICET)

\begin{abstract}
Bovine Leukemia Virus (BLV) is the etiologic agent of Enzootic Bovine Leukosis, a retrovirus exogenous to the bovine species. Once infected, there is no detectable viraemia but instead there is a strong and persistent immunological response to BLV structural proteins, essentially the gp51 envelope glycoprotein and the mayor core protein p24. We describe the test procedure of an indirect ELISA (I-ELISA) using polyclonal reagents for the detection of antibodies to BLV. For comparison, the sera were simultaneously tested by agar gel immunodiffussion (AGID) test, which is currently used as diagnostic standard for BLV infection. The antigen applied does not require a high degree of purification and the data from the analysis of the negative sera showed that the establishment of a cut-off level corresponding to 3 times the standard deviation (SD) above the mean for the negative control set of sera provided acceptable specificity, reducing the risk of false positives results. A comparison of the results obtained by AGID test and I-ELISA showed that considering a total of 465 serum samples, all of the 234 samples $(50 \%)$ that were positive by AGID were positive to the I-ELISA. Of 225 serum samples which yielded negative results in the AGID test, 69 (15\%) were found to be positive by the I-ELISA and $156(33 \%)$ were negative by both techniques. Few sera (2\%) that were non-specific by AGID were defined as negative or positive by I-ELISA.
\end{abstract}

Key words: Bovine Leukaemia; indirect ELISA; seroepidemiology

\section{INTRODUCTION}

Bovine Leukaemia Virus (BLV) is the etiological agent of Enzootic Bovine Leukosis (EBL), a retrovirus exogenous to the bovine species. EBL is highly contagious and cattle become infected by transfer of BLV lymphocytes. The disease can be present without obvious clinical signs as persistent lymphocytosis, a benign proliferation of lymphoid cells, or lymphocarcinoma. Once infected, there is no detectable viraemia but instead there is a strong and persistent response to BLV structural proteins, essentially the gp51 envelope glycoprotein and the mayor core protein $\mathrm{p} 24$.

The control and eradication of EBL is based on detection of antibodies against BLV. Our preliminary

\footnotetext{
* Corresponding author. Mailing address: Area of Virology, Faculty of Veterinary Sciences, National University of La Plata, 60 y 118 , La Plata (1900), Argentina. Fax (+5554) 221-4253276. E-mail: etgonzal@fcv.medvet.unlp.edu.ar
} 
experience was in applying the Agar Gel Immunodiffussion (AGID) test. The simplicity, reliability and economical advantages of this test performed on individual sera have been extremely important for epidemiological studies and are the only official serological test in Argentina. Since both eradication programmes and surveys determining disease prevalence require testing of a large number of samples, there has been continued interest in methods more suitable than the AGID test for largescale application.

Considerable effort has been spent evaluating various technical modifications and practical uses of the ELISA test $(1,2,3,4,6,7,8,9,11,12,13,14$, $15,16,17,18,19,21,22)$. However, not always the results obtained were entirely satisfactory and the routine use in clinical laboratories is therefore restricted. Naif et al. (12) demonstrated false negative readings for some herds even with new generation kits.

In this communication we describe the test procedure of an indirect ELISA (I-ELISA) using polyclonal reagents for the detection of antibodies to BLV and determine the sensitivity, specificity and predictive value of the test. For comparison, the sera were simultaneously tested by AGID test, which is currently used in many countries around the world as a diagnostic standard for BLV infection.

\section{MATERIALS AND METHODS}

Antigen: The persistently infected cell line FLKBLV (kindly supplied by the National Institute of Animal Health, Tsukuba, Japan) was grown in polystyrene tissue culture flasks (Corning) in Dulbecco's modified Eagle's medium (Nissui Pharmaceutical CO. Ltd, Japan) with antibiotics (penicillin $100 \mathrm{IU} / \mathrm{ml}$, dihydroestreptomycin $100 \mu \mathrm{g} /$ $\mathrm{ml}$ ) and supplemented with tryptose phosphate broth (TPB) $0.28 \%$, glutamine $0.03 \%$ and $8 \%$ of foetal calf serum. After the complete monolayer was established, the cultures were washed 3 times with sterile Phosphate Buffer Saline (PBS) and medium without foetal calf serum was added. The supernatant fluid of cultures was harvested on 10 occasions; each separated by five days. The final volume was cleared by centrifugation at $12,000 \times \mathrm{g}$ for $30 \mathrm{~min}$. Ammonium sulphate was used for the overnight precipitation of viral particles. After centrifugation at $6,000 \mathrm{xg}$ at $4^{\circ} \mathrm{C}$, the obtained pellet was dialysed against PBS and concentrated with polyethylene glycol (PEG 6,000) at a concentration 1,000-fold of the initial volume. Disruption of the virus was performed at $0^{\circ} \mathrm{C}$ with Triton $\mathrm{X} 100,1 \%$ for $1 \mathrm{~h}$. The preparation was cleared by centrifugation at $10,000 \times \mathrm{g}$ for $15 \mathrm{~min}$. at $4^{\circ} \mathrm{C}$. This crude antigen was available at a concentration between 33 and $60 \mathrm{mg} / \mathrm{ml}$ protein and stored in $0.1 \mathrm{ml}$ aliquots at $-20^{\circ} \mathrm{C}$ until used as the ELISA antigen.

I-ELISA: Polystyrene microtitration plates (Maxisorp F 96 Immuno Plate; Nunc) were used. Hundred microliters per well of the previous selected antigen dilution (using carbonate-bicarbonate buffer $0.05 \mathrm{M} \mathrm{pH}$ 9.6) was used. After incubation overnight at $4^{\circ} \mathrm{C}$, the plates were washed three times $(5 \mathrm{~min}$. each) with PBS containing $0.05 \%$ Twin 20 and skimmed milk powder $0.2 \%$ (PBS-T-SMP). To standardise the method each volume of serial two fold dilutions of reference positive and negative control sera starting from a 1:20 dilution were performed in PBS-T-SMP $(0.050 \mathrm{ml} / \mathrm{well})$ and incubated overnight at $4^{\circ} \mathrm{C}$. The plates were then washed three times, 5 min. each with PBS-T, and $0.050 \mathrm{ml}$ of a $1: 1,000$ dilution of horseradish peroxidase-labelled rabbit antibovine immunoglobulin G (Dakopatts) in PBS-T-SMP was added. After being incubated for $1 \mathrm{~h}$ at $37^{\circ} \mathrm{C}$, the plates were washed, and substrate solution was added: 2.2'-Azino diethyl-benzothiazoline sulfonic acid (ABTS), Boehringer Mannheim, Germany $10^{-4} \mathrm{M}$ in citrate phosphate buffer $(0.1 \mathrm{M}) \mathrm{pH} 4.0$ and $10^{-3} \mathrm{M}$ $\mathrm{H}_{2} \mathrm{O}_{2}$. After incubation for $35 \mathrm{~min}$. the optical density (OD) at $405 \mathrm{~nm}$ was measured in a microplate spectrophotometer (Multiskan, Flow Laboratories). For the ELISA of field sera, the samples were tested at 1:20 dilution and each one was run in duplicate. The test was carefully performed in order to get uniform results. On each microplate, known negative and positive sera were added.

The results were expressed as following: (Xs $\mathrm{Xn}) /(\mathrm{Xp}-\mathrm{Xn})$

Were Xs: Average of two serum sample readings

$\mathrm{Xn}$ : Average of two negative control serum readings

$\mathrm{Xp}$ : Average of two positive control serum readings

The negative and positive control samples (giving a negative and positive reaction in the AGID test, respectively) were obtained from cattle from geographic regions in which BLV infection was nonendemic (patagonic region) and endemic respectively (central region).

Sera: The following groups of sera were used in this experiment: 
1) Sera collected from 99 cattle (between 2 to 3 years old) belonging to three herds which had been proved to be free from BLV infection during 3 consecutive investigations applying AGID test with 3 months interval.

2) Four reference sera: A local positive bovine antiBLV, a European reference positive serum (E4, Council Directive 64, EEC, July 1988, Annex G), a negative bovine anti-BLV and a positive bovine anti-BVDV (kindly supplied by NIAH, Tsukuba, Japan and the Virology Institute, INTA, Castelar, Argentina).

3) 465 serum samples (between 1 to 8 years old) obtained from different geographical regions of Argentina. These bovine serum samples were previously tested by the AGID test.

AGID test: This test (10) was performed on all the samples with a commercial kit produced in our laboratory (approved by SENASA, National Service for Animal Health, Argentina). Agar plates were placed in humidified trays and incubated at $37^{\circ} \mathrm{C}$ for $1-3$ days. The AGID test detects undiluted positive reference sera and E4 diluted 1:10 in negative serum (Council Directive 64, EEC, July 1988, Annex G) as weak positive.

\section{RESULTS}

The choice of the optimal concentration of antigen used for the coating onto the wells was based on obtaining maximal absorbance readings for BLVpositive control samples and minimal background values for BLV-negative control samples (Fig. 1). The coated plates were usually used immediately but could be stored at $4^{\circ} \mathrm{C}$ for up to 3 months without a decrease in reactivity. As shown in Fig. 1, for all concentrations of the antigen tested, there was no increase in the background values from BLV-negative control samples. An optimal level of discrimination between positive and negative control samples was obtained with protein concentrations ranging between 77 to $192 \mathrm{mg} / \mathrm{ml}$ (equivalent to a dilution 1:500 to 1:1,000. of the original antigen preparation). An antigen working concentration of a $1.910^{-2} \mathrm{mg}$ of total protein by well (dilution: $1: 1,000$ ) was selected and used for coating onto the wells throughout this study.

The more convenient dilution of the serum samples should provide a quantitative answer derived from the average of two readings at a determined dilution. We choose a working dilution of samples 1:20 at which both, the positive and negative control samples gave reliable results.

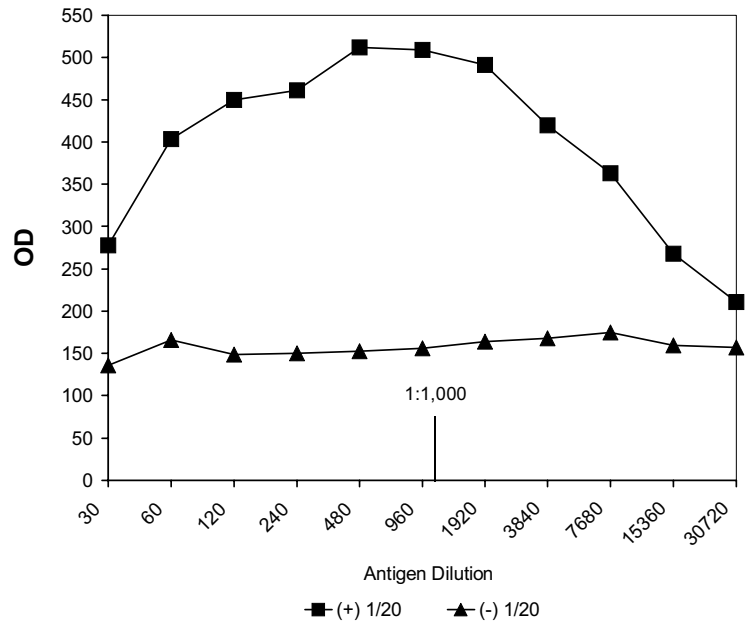

Figure 1: Titration curves of the I-ELISA antigen using AGID positive and AGID negative sera

For determination of a reliable cut-off, a total of 99 serum samples from BLV-free herds were used to determine the normal range of variability applying the I-ELISA test. The I-ELISA values of these sera showed a normal distribution as shown in Fig. 2. Therefore, assuming a $1 \%$ probability of misclassification (mean value plus 3 standard deviation, $X+3 \mathrm{SD}$ ), the upper limit of an ELISA value for the negative population was determinated as 0.18 . On the basis of these results, cattle with ELISA values of more than 0.18 were regarded as positive reactors.

Specificity of I-ELISA: Since some sublines of FLK-BLV are known to be contaminated with BVDV, anti-BVDV reference sera were tested against our I-ELISA system. Sera having antibodies to BVDV, but not to BLV, showed no reaction in the ELISA, although sera having antibodies to BLV, but not to BVDV, showed a positive reaction. As was expected, reference European positive serum E4 (originally diluted 1:10 in negative serum) gave a positive result.

A comparison of the results obtained by the AGID test and ELISA is shown in Table 1. A total of 465 serum samples previously tested by the AGID technique were subjected to the I-ELISA. All of the 234 samples that were positive by AGID were positive by ELISA $(50 \%)$. Of 225 serum samples which yielded negative results in the AGID test, 69 sera (15 $\%)$ were found to be positive by the I-ELISA. From 6 sera $(2 \%)$ non-specific by AGID, 3 were negative and 3 were positive by I-ELISA. None sera negative by IELISA was positive by AGID. 
a)

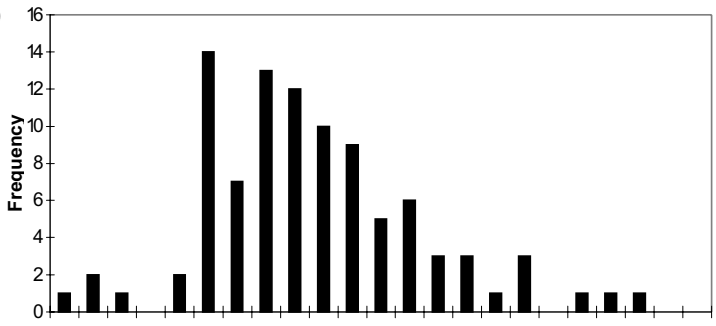

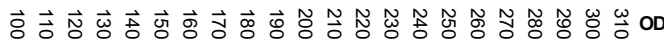

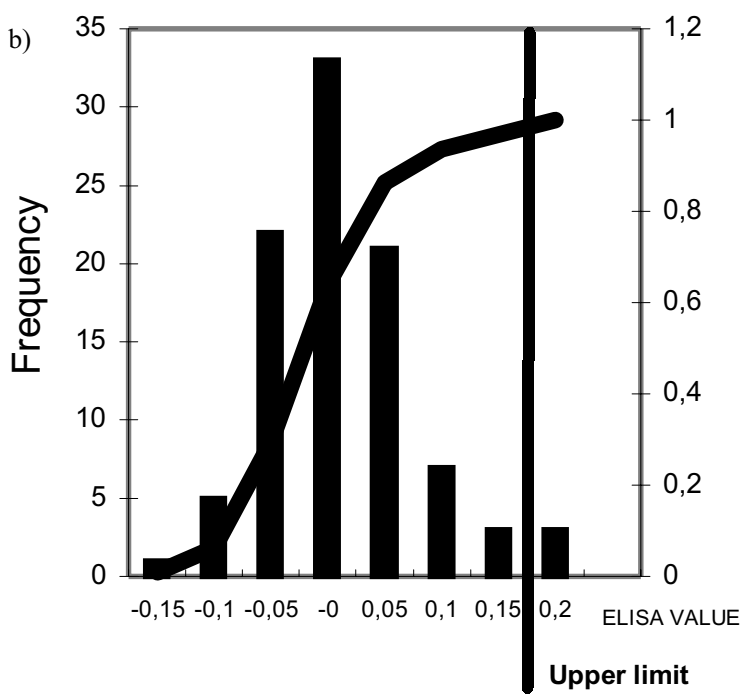

Figure 2: a) Distribution of I-ELISA values of sera collected from BLV free herds. b) Normal distribution of calculated values of negative serum samples applying I-ELISA. All sera showing I-ELISA values more than 0.18 (mean value plus 3 standard deviation, $X+3 \mathrm{SD}$ ) were considered positives.

Table 1: Comparison of results obtained with 456 serum samples using AGID and I-ELISA

\begin{tabular}{cccc}
\hline & ELISA + & ELISA- & Total \\
\hline AGID + & $234(50 \%)$ & $0(0 \%)$ & 234 \\
AGID- & $69(15 \%)$ & $156(33 \%)$ & 225 \\
AGID non-spec. & $3(1 \%)$ & $3(1 \%)$ & 6 \\
\hline Total & 306 & 159 & 465 \\
\hline
\end{tabular}

\section{DISCUSSION}

This article reports the evaluation of an I-ELISA developed in our laboratory and its comparison with the AGID technique, which is currently used as a diagnostic standard for BLV infection. However, the interpretation of AGID results is sometimes subjective and reliability depending on a great extent on the training and experience of the laboratory personnel.
The sensitivity of both tests strongly depends on the quality of the BLV antigen used. Impurities cause relatively high background values or non-specific reactions. In general, the use of highly purified antigen significantly increases the cost of the test. In this IELISA test the antigen applied does not require a high degree of purification. In consequence, purification by sucrose-gradient followed by pelleting was not necessary.

Since pre-coated plates can be prepared in advance and stored at $4^{\circ} \mathrm{C}$ for at least 4 month, this I-ELISA reduces by less than 2 days the time required for BLV serological detection.

For any given serological test, sensitivity and specificity are determinated by the cut-off value. There are considerable benefits associated with standardised diagnostic tests, particularly in relationship to export testing, animal health regulations, and disease control (20). Arbitrary methods include the recommendation of a subjective cut-off value or use of a statistical parameter (such as $3 \mathrm{SD}$ above the mean for the negative control set of sera). Our main effort was to focus on overcoming the inherent problem of significant background associated with the indirect technique. The data from the analysis of the negative sera showed that the establishment of a cut-off level corresponding to 3 times the SD above the mean for the negative control set of sera, provided high specificity, reducing the risk of false positives results. We established a reliable cut-off working with high number of negative sera -99- from animals of different ages and from three different areas. Our current cutoff value (0.11: $2 \mathrm{SD}$ ) or another somewhat lower value is appropriate for pre-export testing by exporters to ensure that very few false-negative diagnoses are made. This value is in accord with Ridge et al. (20) who pointed out that the two extreme cut-off values, 0.05 and 0.25 represent the points that provide nearly perfect sensitivity and perfect specificity, respectively. Depending on analytical variation, it is possible, within certain limits, to select a lower cutoff level, in order to increase sensitivity with only a slight reduction in specificity (4). The cut-off value could be changed to a higher value (in our case 0.18 $3 \mathrm{SD}$ ) for almost all routine diagnostic testing and for herds for which a planned eradication program is undertaken.

As with many infections, the initial appearance of the antibodies at detectable levels and their continuing detection during long periods even using a very sensitive test, may depend upon differences in the 
immune system of individual cattle, as well as upon other factors such as persistent infection with bovine viral diarrhoea virus (BVDV) which has been shown to depress antibody responses to BLV.

Comparing our results from the I-ELISA and AGID tests, they were found to agree in the vast majority of cases but ELISA sensitivity was found to be higher than the AGID test. The epidemiological significance of I-ELISA positive but AGID negative cattle is that they might be a source of BLV infection.

Both tests are used routinely in the laboratory because ELISA may complement the AGID test in a number of cases. The AGID test run in optimal conditions is the most practical, cheapest and easiest technique with high sensitivity. Besides, the crucial point is that the ELISA test system includes a number of steps and must be correctly carried out with trained operators.

\section{ACKNOWLEDGMENTS}

The authors are grateful to Dr. A. Valera, CEDIVE, Fac. Vet. Sci. UNLP, Argentine and Dr. G. Freneau, Escola de Veterinaria, Univ. Fed. Goiás, Goiânia, GO, Brazil.

\section{RESUMO}

\section{Leucose Enzoótica Bovina: desenvolvimento de um teste ELISA indireto (ELISA-I) e sua aplicação em estudos epidemiológicos}

O Vírus da Leucose Bovina (VLB) é o agente etiológico da Leucose Enzoótica Bovina, um retrovirus exógeno da espécie bovina. Uma vez infectado, não se detecta viremia, mas uma forte e persistente resposta imunológica às proteínas estruturais, sobre tudo para gp51 da coberta e para proteína p24 do core. Neste trabalho se descreve o desenvolvimento de um ELISA indireto (ELISA-I), em que se utiliza o soro policlonal para a detecção de anticorpos para VLB. Os soros foram analisados pela prova de IDGA (imunodifusão dupla em gel de ágar) rotineiramente usada como prova padrão. $\mathrm{O}$ antígeno escolhido não necessita de alto grau de purificação e os resultados obtidos com os soros negativos permitiram estabelecer um valor de corte de três desvios padrão (DP) sobre a média do grupo de soros negativos, mostrando aceitável especificidade e reduzindo o risco de falsos positivos. A comparação dos resultados conseguidos por IDGA e ELISA-I demonstrou que em um total de 465 soros, 234 (50\%) foram positivas por IDGA e ELISA-I. Dos 225 soros negativos por IDGA, $69(15 \%)$ foram positivos por ELISA-I e 156 (33\%) foram negativos pelas duas técnicas utilizadas. Apenas $2 \%$ dos soros foram inespecíficos por IDGA e se definiram como positivos ou negativos pelo ELISA-I

Palavras-chave: Leucose Bovina; ELISA indireto; estudos epidemiológicos.

\section{REFERENCES}

1. Carli, K.T.; Batmaz, H.; Sen, A.; Minbay, A. Comparison of serum, milk and urine as samples in an enzyme immunoassay for bovine leukaemia virus infection. Res. Vet. Sci. 55: 394-395, 1993.

2. Florent, G.; Delgoffe, J.C.; Zygraich, N. La détection de la Leucose Bovine Enzootique a l'aide d'un Test ELISA effectué sur le lait. Rec. Méd. Vét. 164: 1021-1024, 1988.

3. Gielkens, A.L.J.; Ressang, A. A.; Ijzermann, J.; Quak, J. Test protocol of an enzyme-linked immunosorbent assay (ELISA) for the detection of antibodies against bovine leukosis virus. The Vet. Quarterly 3: 34-37, 1981.

4. Have, P.; Hoff-Jorgensen, R. Demonstration of antibodies against bovine leukemia virus (BLV) by blocking ELISA using bovine polyclonal anti-BLV immunoglobulin. Vet. Microbiol. 27: 221-229, 1991.

5. Klintevall, K.; Ballagi-Pordány, A.; Näslund, K.; Belák, S. Bovine leukaemia virus: Rapid detection of proviral DNA by nested PCR in blood and organs of experimentally infected calves. Vet. Microbiol. 42: 191-204, 1994.

6. Knapen, K.; Kerkhofs, P.; Thiry, E.; Mammerickx, M. Epidemiological evaluation of a monoclonal ELISA detecting antibodies against bovine leukaemia virus in serum pools. Epidemiol. Infect. 113: 563-569, 1994.

7. Mammerickx, M.; Portetelle, D.; Bruck, C.; Burny, A. Use of an ELISA Involving Monoclonal antibody for the detection of antibodies against Bovine Leukemia virus in a herd with a high incidence of Enzootic Bovine Leukosis. Zbl. Vet. Med. B, 31: 210-218, 1984

8. Mammerickx, M.; Portetelle, D.; Burny, A. Application of an Enzyme-Linked Immunosorbent Assay (ELISA) involving Monoclonal Antibody for Detection of BLV Antibodies in Individual or Pooled Bovine Milk samples. Zbl. Vet. Med. B, 32: 526-533, 1985.

9. Mammerickx, M.; Portetelle, D.; Nys, J.; Burny, A. Rapid Detection of Bovine Leukaemia Virus Infection in a large Cattle Population with an ELISA performed on Pooled sera Grouped by Herd. Zbl. Vet. Med. B, 32: 601-608, 1985.

10. Miller, J.M.; Van Der Maaten, M.J. Serological detection of bovine leukemia virus infection. Vet. Microbiol. 1: 195-207, 1976.

11. Moreno, E.; Dolz, G.; Bonilla, J.; Jimenez, C.; Rodriguez, L.; Salazar, I.; Ramirez, M.; Bolaños, E.; Mora, M.; Silva, S. Serological studies on Bovine Leukemia Virus (BLV) infection in Costa Rica by ELISA, Immunodiffussion and Western Blot Tests. Proceedings, Regional network for Latin America on animal disease diagnosis using immunoassay and labelled DNA probe techniques, IAEA. Vienna: 99-114, 1992.

12. Naif, H.M.; Daniel, R.C.W.; Cougle, W.G.; Lavin, M.F. Early Detection of Bovine Leukemia Virus by using an Enzyme-Linked assay for Polymerase Chain Reaction-Amplified Proviral DNA in Experimentally Infected Cattle. J. Clin. Microbiol. 30: 675$679,1992$. 
13. Nguyen, V.K.; Maes, R.F. Evaluation of an Enzyme-Linked Immunosorbent Assay for Detection of Antibodies to Bovine Leukemia Virus in Serum and Milk. J. Clin. Microbiol. 31:979981, 1993.

14. Noda-Gomez, J.; Perez, M.; Marreras, M.; Abeledo, M. A. The use of ELISA and Nucliec Acid Hybridization Test in Reserch and diagnosis of Bovine Leukosis Virus. Proceedings, Regional network for Latin America on animal disease diagnosis using immunoassay and labelled DNA probe techniques IAEA. Vienna: 85-98, 1992.

15. Platzer, C.; Siakkou, H.; Kraus, G.; Gröbel, C.; Rosenthal, S. Use of Monoclonal Antibody against Major Internal Protein p24 of Bovine Leukemia Virus in Capture ELISA. Arch. Exper. Vet. Med. 44: 917-923, 1990

16. Portetelle, D.; Bruck, C.; Mammerickx, M.; Burny, A. Use of Monoclonal Antibody in an ELISA test for the detection of antibodies to bovine Leukaemia Virus. J. Virol. Methods 6: 1929, 1983.

17. Portetelle, D.; Burny, A.; Desmettre, P.; Mamerickx, M.; Paoletti, E.; Zavada, J. Development of a specific serological test and an efficient subunit vaccine to control Bovine Leukemia virus infection. Develop. Biol. Standard. 72: 81-90, 1990.
18. Portetelle, D.; Mammerickx, M.; Burny, A. Use of two monoclonal antibodies in an ELISA test for the detection to bovine leukaemia virus envelope protein gp51. J. Virol. Methods 23: 211-222, 1989.

19. Ressang, A.A.; Gielkens, A.L.J.; Quak, J.; Mastenbrock, M.N. Studies on Bovine Leukosis: VII. Further experience with an ELISA for the detection of antibodies to bovine leukosis virus. The Vet. Quarterly 3: 31-33, 1981

20. Ridge, S.E.; Vizard, A.L. Determination of the Optimal Cutoff Value for a Serological Assay: an Example Using the Johne's Absorbed EIA. J. Clin. Microbiol. 31, 5: 1256-1261, 1993.

21. Takahashi, K.; Kono, Y. Development of Practical ELISA for Detection of antibodies to Bovine Leukaemia Virus: A comparison of its sensitivity with that of virus Neutralization and Agar Gel Immunodiffussion Test. Jpn. J. Vet. Sci. 47: 193200, 1985.

22. Vidziunaité, R.; Dikiniené, N.; Miliukiené, V.; Mikulskis, P.; Kulys, J. Chemiluminescence ELISA for the Detection of Antibodies to Bovine Leukaemia Virus Antigens. J. Biol. Chem. 10: 193-198, 1995 